\title{
What Money Can't Buy: The Moral Limits of Markets
}

In What Money Can't Buy, Sandel examines one of the biggest ethical questions of our time and provokes a debate that's been missing in our market-driven age: What is the proper role of markets in a democratic society, and howcan we protect the moral and civic goods that markets do not honour and money cannot buy? Gil Shidlo feels that Sandel brings the issue to be debated and raises it in a way each one of us feels fully equipped to voice concerns.

\section{What Money Can't Buy: The Moral Limits of Markets. Michael Sandel. Allen Lane. May 2012.}

\section{Find this book:}

Yet again, Michael Sandel, one of the most relevant philosophers of our times, forces us to take a closer look at moral aspects of our lives. Following the success of his previous book Justice, What Money Can't Buy pushes us to re-examine attitudes, values and norms which govern social and civic life.

Though many of us seem troubled by commodification of certain aspects of social and civic life, most of us tend to accept it in order to avoid a public debate. Like many relevant philosophers before him, Michael Sandel, a professor of politics at Harvard, is trying very hard to reform us and turn us from mere acquiescent individuals into full participants in the shaping of social and civic life. He pushes us to voice our concerns and debate them without deflecting from the importance of morality in the choices we make.

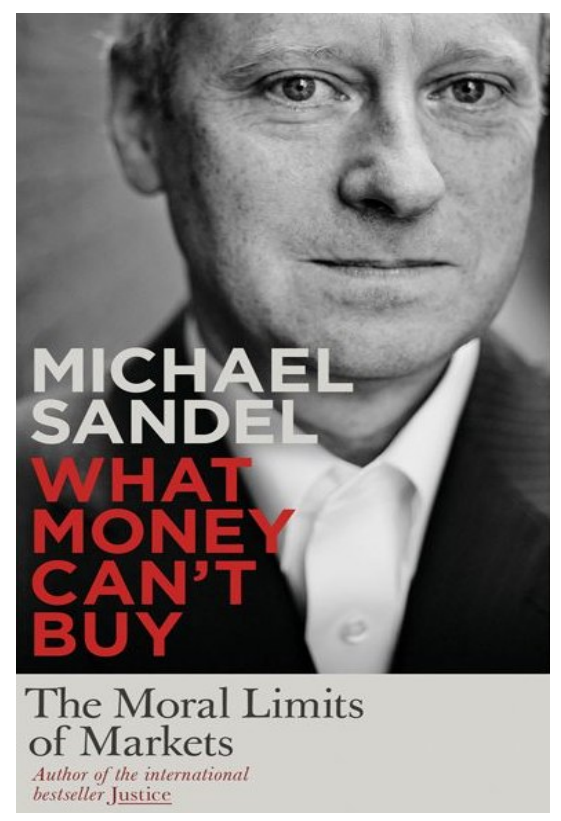

What Money Can't Buy looks closely at the moral implications for a society where virtually everything is for sale and where market economy is used to allocate everything from health to education to public safety and criminal justice. Michael Sandel gives examples from various US states: in California a nonviolent offender can pay for a prison cell upgrade; in other states single drivers can pay for use of car pool lanes; $24 / 7$ access to your doctor can be bought for $\$ 1500$ a year and above; admission of your child to a top US university; fast track at airport security; paying for people to stand in line for you to attend a Congressional hearing.

The problem is compounded further when markets are no longer inert. What commodification does is create a greater inequality and stronger possibility of corruption by not only putting price on goods but also altering attitudes towards certain type of goods. The book suggests that if markets in social goods are no longer inert, some of the good things in life are corrupted and we have debased their moral value and by it endangered the existence of orderly society. This, in turn, raises the need to look closely at these goods and try to find different ways to value them without stripping them of their moral or political value.

The debate raised by this book is forcing us to recognize that civic duty may not be treated as private property and as such cannot be given monetary value. Where commodification takes place it is highly likely to create greater inequality and corruption and this in turn jeopardizes the existence of orderly society. 
Sandel describes new ways of making money if you cannot afford the services mentioned in the book. One can rent space on one's body to advertise; or serve as a human guinea pig for a big pharmaceutical company; or work for a line-standing company for those lacking in time but wishing to attend a free concert or hear the Pope. Even young children get paid nowadays - second grade children in Texas schools get paid $\$ 2$ to read a book; obese people are paid to lose weight in a targeted time frame. One can even try and profit by buying the life insurance policy of an elderly person. In this case, we would pay the premium while the person is alive and collect the death benefit. While the objective of a life insurance was to help the family survivors in this case the investor profits more if a person dies sooner. Thus, life insurance is an example of how market values can change the character of an industry. Michael Sandel writes how Walmart (the largest retail company in the world) took this concept one step forward. It insured the lives of hundreds of thousands of its employees and every time one of them died Walmart benefited from it rather than the family of the deceased.

It seems there is hardly any service or good which one cannot buy in this new market society. The list of what money cannot buy is rather short - for example friendship; a Noble Prize or an Olympic Prize (although some medals have been sold the honor of being awarded the prize cannot be sold).

But the fact that we acquiesce to these new practices where everything may be monetarily quantified is seriously questioned in this book. There are some critics who think the book does not go far enough by adopting a more prescriptive approach. In my view, Sandel fully fulfills what any scholar would have liked to see, and even takes it one full step forward - he brings the issue to be debated and raises it in a way each one of us feels fully equipped to voice concerns. There is no need to be a scholar or a philosopher of some stature to question attitudes, values and norms. Michael Sandel has brought all different elements of society to face the problem, debate it and stop society from unraveling. I truly applaud a scholar, who has successfully taken a philosophical debate outside of the confined space of a classroom, in a manner that gives all of the participants the power to affect change.

\section{Watch Michael Sandel's discussion on The Moral Limits of Markets}

Gil Shidlo took his $\mathrm{PhD}$ in political science at the LSE. After working in academia and international organizations, his main interests have focused on investing in stock markets. He contributes regularly to Moneynews.com as well as the Financial Intelligence Report. Most recently he has been studying the increasing role of private equity funds in taking over formerly government assets and companies on both side of the Atlantic. Read more reviews by Gil.

Related posts:

1. Book Review: Paper Promises: Money, Debt and the New World Order, by Philip Coggan (5.3) 